\title{
Changing students, changing teaching: Understanding the dynamics of adaptation to a changing student population
}

\author{
Yatta Kanu \\ University of Manitoba \\ kanuy@ms.umanitoba.ca
}

\begin{abstract}
As global migrations increase, educators search for effective ways of meeting the learning needs of diverse student populations. I explore this challenge in a study conducted at the high school level where concerns about student diversity and subject matter intersect sharply. Using a case study approach to understand the dynamics of teachers' adaptations to changing student populations, I document adaptations made by Math and English teachers in a large Canadian city in the areas of curriculum, instruction, and assessment. I examine the goals, conceptions of subject matter, instructional practices, and views about student learning held by Math and English teachers; the teachers contrast as to whether they did or did not reconceptualize and change their practices when faced with new populations of students, specifically African refugee students. I also examine ways in which the teachers' school contexts, for example, their subject departments, facilitated or inhibited change in their teaching practices. I conclude that different patterns of goals, conceptions of subject matter, and beliefs about students characterize teachers who adapt and those who do not. In the light of these findings I urge teacher education programs to reconsider their exclusive focus on multicultural competence and take these patterns/elements into account in the preparation of teachers for working successfully with changing student populations.
\end{abstract}

\section{Introduction}

....I am lucky, I have a lot of freedom with my curriculum. So as the student population has changed in my school, so have my curriculum and my teaching. So I choose books and topics based on the students I have.... (Shirley Jones, English teacher, June Halloway High School ${ }^{1}$ ).

Well, you know what? I really wish we could do something more for these students because I feel bad for them, but my hands are tied. When you have students especially coming into pre-calculus class and they don't have the skill, I really feel bad but if I slow down, then the kids who deserve to have the course are cheated....

(Elizabeth Polsky, Math teacher, June Halloway High School).

These teachers both teach at June Halloway High School, a school which has experienced dramatic changes in its student population over the past ten years. Both are

Cultural and Pedagogical Inquiry, 2009, 1(1), pp.22-39

ISSN 1916-3460 (C) 2009 University of Alberta

http://ejournals.library.ualberta.ca/index.php/cpi/index 
committed, hardworking teachers who have taught for many years and want their students to succeed in school and outside of school. What then accounts for Shirley Jones' willingness to change her classroom practice to meet the needs of her changing student population while Elizabeth Polsky feels frustrated and unable in the face of similar changes? As students in Canadian schools become more diverse in terms of race, ethnicity, culture, religion, socio-economic class and languages spoken in the home, the answers to these questions become increasingly important to educators and policy makers alike.

Although June Halloway High School has always had new immigrant students, the past ten years have seen an unprecedented increase in the number of students who are racially, culturally, and linguistically different from those of the Canadian mainstream (- from 5\% in 1998 to $20 \%$ in 2007. In the province of Manitoba, where the study was conducted, there has been a consistent growth trend in both overall immigration and the number of refugee immigrants since 1998. For example, 8,093 refugees immigrated to the province between 1998 and 2005, with the school-age population of refugee newcomers (0-24 years) constituting approximately half of that number (Morrish, 2006). According to Mackay \& Tavares (2005), the vast majority of these newcomer refugees are from Africa and the Middle East.

Similar growth trends in refugee and overall immigration in other Canadian provinces, as well as in other western industrialized countries, have presented teachers with unique challenges and opportunities in their classrooms. Over the years different responses to these challenges and opportunities have emerged. For example, the multicultural approach has emphasized the enhancement of teachers' knowledge and appreciation of cultural differences so that they can use culturally compatible curriculum resources and pedagogical practices to increase the chances of school success for cultural minority students (Banks, 2008; Darling-Hammond \& Bransford, 2005). Socio-cultural theorists of learning (Vygotsky, 1981; Cole \& Wertsch,1996) have focused on the intricate connection between classroom learning and learners' prior cultural socialization and have proposed the integration of students' cultures into the school curriculum to bridge the gap between the home and the school. Others have argued that in order to tap the riches of diversity, teachers must first believe that difference does not equal deficit (Nieto, 1996); therefore teachers must genuinely respect students from different backgrounds and be receptive to the funds of knowledge that students bring to the schooling process (Abowitz \& Harnish, 2006). Still others, such as Knapp (1995) and Page (1991), have identified teacher motivation and expectations for students as crucial factors in success when working with more diverse students.

As this brief review of the literature shows, a number of critical elements of effective teaching with diverse students have been identified over the years. What we know much less about is why some teachers choose to adapt their teaching practices for a changing student population and others do not. What factors contribute to teachers' willingness and ability to adapt their classroom practices? Relatively little research has explored this question, particularly at the high school level where issues of student diversity intersect with concerns about subject matter.

In this study, I adopt a broad conceptual framework to explain the differences in high school English and Math teachers' willingness and ability to adapt their teaching practices for a changing student body. I define adaptation as the changes teachers make 
in order to respond successfully to a changing student population. According to Stodolsky and Grossman's (2000) 'continuum of adaptation', adaptations range from minimal alterations, through adjustment of curriculum pace and coverage, to qualitative reconceptualization of practice in order to facilitate student learning.

\section{Conceptual framework}

The conceptual framework of this study draws on insights from previous work by Grossman \& Stodolsky (1995) and Stodolsky \& Grossman (2000) to explicate the factors that play an important role in influencing how teachers respond to a more diverse student body in their schools. Grossman and Stodolsky (1995) posit that, in addition to an understanding of cultural and linguistic diversity, three levels of factors influence teachers' willingness and ability to adapt their practices in the face of a changing student population: 1. subject matter context; 2. individual teacher characteristics; and 3. local school contexts. Subject matter context refers to teachers' conceptions of their subject matter and teachers' teaching goals. Stodolsky and Grossman (2000) point out that Math and English teachers, for example, differ in their conceptions and goals for their subject matter. Math teachers generally consider their subject to be sequential, requiring topic coverage in a set order, with knowledge viewed as relatively static, cut and dry, and subject to little change. These perceptions have been associated with Math teachers' preoccupation with topic coverage, presumed lack of autonomy in selecting what to teach in their courses, and primary focus on student mastery of specific content. By contrast, English teachers generally perceive their subjects as less sequential and more amenable to change. English teachers also tend to strongly endorse multiple goals that include not only subject matter mastery but also personal growth and the development of self-esteem and positive human relations. Math teachers do not reject multiple goals but their endorsement of them is less strong and they place more emphasis on content mastery. These differences in goals and subject matter conceptions may have consequences for teachers' willingness and ability to adapt to diverse learners.

Stodolsky and Grossman (2000) also posit individual factors such as individual teachers' beliefs about students, instructional repertoire, and knowledge and skill in the subject as key factors affecting individual teachers' willingness and ability to change instructional practices when faced with a new student population. Teachers who feel confident about their content and pedagogical content knowledge, and who have high expectations for students' success, are also more likely to adapt than teachers with a strong commitment to the practices they currently use and no confidence of success with new pedagogical approaches.

Teachers are also likely to need access to new knowledge and support as they embark upon new instructional practices, hence the importance of the role of the local school context, such as the subject department, in facilitating teacher change. Departments with strong collegial interaction and commitment in support of student learning help teachers gain access to needed instructional approaches and resources, thereby increasing teachers' personal and collective efficacy (the belief that they are capable) for responding to the learning needs of new student populations. Shared norms and beliefs as well as the actual conditions teachers confront in their daily work--such as 
teaching load, teacher assignment, available resources, and other supports--can contribute in important ways to teachers' willingness and capacity to make instructional changes.

In this study, I examined how these three factors-subject matter context, individual teacher characteristics, and local school contexts - contributed to high school teachers' responses to a changing student population, specifically African refugee students.

\section{The study}

This exploration of teacher adaptation is part of a larger study led by this author on the educational needs and barriers for African refugee students in the western Canadian province of Manitoba. Case studies of two Math and two English teachers from two inner-city high schools with high populations of African refugee students $(15-20 \%)$ were used to investigate the dynamics of adaptation to African refugee students by these teachers. Four specific questions were explored for this aspect of our study: What adaptations do Math and English teachers make to promote academic success among African refugee students? What are teachers' conceptions of their subject matter and how do these conceptions facilitate or constrain adaptation in curriculum and instruction? Do teachers who try to adapt to new students hold different views, beliefs, and instructional repertoire than those who do not? How do local school contexts, like the subject department, enable or hinder adaptation to new practices?

\section{Research procedures}

The central concern of the study was to understand why individual teachers do or do not alter their teaching practices in response to a changing student population. Over one academic year (2006-2007), the research team (myself and two graduate research assistants) interviewed and observed the classrooms of four teachers teaching African refugee students in two inner-city high schools in the same school division in a large urban center in Manitoba. The selection of the teachers was based on their willingness to participate in the study. Math and English teachers were selected because African refugee students participating in previous focus groups and individual interviews had identified Math and English as the school subjects with which they were having the most difficulty. All four teachers were reputed to be competent teachers, each committed to teaching for understanding and for the academic success of their students.

Our interviews with the case study teachers explored each individual teacher's conceptions of his/her subject matter, teaching goals, views about student learning, perceptions about African refugee students and their academic success, instructional practices, senses of efficacy, adaptations in curriculum and teaching practices in response to the African refugee students, and supports from their school and subject departments.

In addition to the interviews, each teacher's classroom was observed at least twice. Classroom observations focused on the teachers' instructional repertoires, studentteacher interactions, adaptations in curriculum and instruction, and other learning opportunities created for African refugee students. Collected data were transcribed and analyzed by carefully examining them for what each teacher said and did in regard to their instructional responses to their African refugee students. Drawing on the conceptual framework presented earlier, the nature and types of the reported and observed 
adaptations were coded and analyzed in order to understand the range and types of efforts teachers made to teach these students and the possible dynamics shaping these efforts. Below, I discuss the individual case-study teachers, who represent strong contrasts with respect to the Stodolsky and Grossman (2000) adaptation continuum.

\section{Findings}

\section{English Teacher Shirley Jones}

Shirley Jones had taught English literature at June Halloway High School for 15 years at the time of our study. At the beginning of her career she emphasized the teaching of canonical texts and the writing of analytical essays pertaining to the literature she taught. However, as the student population changed, Ms. Jones began to question the appropriateness of her curriculum for her new student population:

I mean, I am often the only white person in the class. For example, this year I teach one grade 12 class with just five non-immigrant students in the whole class. So I have become increasingly aware that the traditional literature that's expected to be taught doesn't work ...I don't know how it would hit the experiences of these new immigrant kids.

When we observed her, Ms. Jones was teaching literature to grade 12 students and composition and writing to grades 10 and 11 students. Although she repeatedly mentioned that English is simply too comprehensive ("it has too many components and this makes it difficult to teach and for students to learn it") she did not conceive of English as sequential and immutably defined.

As an English teacher I am lucky ... I get a lot of freedom with my curriculum, so as the student population has changed in this school, so have my curriculum and my teaching....so I choose books and topics based on the students I have....

In addition to this autonomy over the curriculum, Ms. Jones also felt strongly that English provided opportunities to get closer to the students, to know them better, and to learn from them:

If you select material that hits their stories and their experiences, rather than throw at them a Shakespearean play from 100 years ago, they begin to open up and speak in class...they become the sources of knowledge rather than the deficit students they are often seen as around here...

The ability of teachers to select the literature they teach was clearly important to Ms. Jones in meeting her teaching goals. Her teaching goals were broad and multifaceted, extending well beyond subject matter. 
Yes, subject matter is important and should be acquired but so are other equally important goals, such as helping students to think clearly, imparting a strong sense of what's right, interpersonal skills, responsible citizenship, good work habits...

\section{Changing students, changing practice}

Shirley Jones saw her evolution as a teacher as intimately connected to the changes she saw in the student population. To begin with, she believed strongly in the importance of establishing ties with students, getting to know them and their backgrounds, and making herself accessible to them. We observed that her classroom/homeroom was where students from different African countries came to "hang out", to meet other African students, to pick up information about new immigrant services, or to find help with filling out citizenship application forms. For her, getting to know these students and building relationships with them was "just common sense" if one wanted to teach them effectively. She explained:

For example, if you know they have gone through horrendous war experiences, that they have only been in Canada for two years or less, that they are working eight hours after school just to survive, that some are running their own households, that they are having a hard enough time understanding English, you know they have all these pressures and so you should know better than to throw Shakespeare at them all at once and expect them to perform well. Some teachers just don't get it; they just don't get it....

Much of the adaptation Ms. Jones made in her teaching was guided by this background knowledge of her students. One of her first and most rewarding initiatives, therefore, was to join other teachers in the English department to form the 'Literacy Group'. This group of teachers is interested in searching for different literacy strategies and effective ways of implementing such strategies for the benefit of their EAL students (English as an Additional Language). Another rewarding initiative for Ms. Jones was becoming a member of the 'Teaching for Diversity' group in her department. She said:

I guess these two initiatives have been rewarding and informative in my evolution as a teacher... By literacy, I mean how best to improve the reading, writing, and comprehension skills of our EAL students. If you ask these students and any of their teachers, they'll tell you upfront that the English language is a major barrier to their academic success.... Now this is an important issue in teaching for diversity....

As a direct response to the difficulties which students in her regular classes were having with comprehending advanced English, Ms. Jones took time to look for more accessible course readings that the students could understand more easily. In her regular English classes she sometimes re-wrote course material in simpler English and took the time to explain Canadian cultural cues in the videos she showed in class "to enhance my EAL students' comprehension of these videos". She also reported that she consistently related course material to students' lives and experiences, explaining: "If you impose 
work that is always too far removed from their personal world, they just can't relate and you lose them..."

Ms. Jones described the changes she made to her grading and assessment of student learning, moving from a rigid conception of "fairness" in assessing student achievement to a more fluid and flexible interpretation of the term. For example, in response to the changing student population in her classes, fairness now meant giving more time to students to complete tests and homework, and allowing African students who had a better understanding of the requirements of a test to explain those requirements to other African students who needed help with comprehending English. She had also prepared tests at different levels of difficulty for students in the same class and passed students based on effort and regular attendance. Ms Jones, however, admitted that her expectations for the students in her regular classes were slightly lower as most of them were not college bound: "I don't do this sort of adaptation with my college bound students because I know they have to take provincial exams...".

Ms. Jones agreed that support from the school administration, colleagues, and the subject department was absolutely essential in enabling teachers to adapt to a new student population. She credited her departmental colleagues for many of the adaptations she had been able to make in her curriculum and teaching:

A number of us in the (English) department agreed right away that we needed to do something to attack the problem (of working with EAL students in regular classes). We formed the 'Teaching for Diversity' group and the 'Literacy Group'. We attend workshops and read materials on literacy skills and share what we learn with each other.

She expressed satisfaction with her teaching load as a result of which she was able to do more for her new immigrant students:

For instance, I have been able to change how I teach writing in my regular classes, from formal essay writing to an emphasis on more personal response forms of writing and I have time to mark those responses and give meaningful feedback to students. I also have sufficient prep time, some of which I use to help new immigrant students fill out applications for part-time work and citizenship applications....

Ms. Jones' only regret was that her department was somehow divided between those who were actively trying to adapt to change and those resisting change.

\section{English Teacher Mark Thompson}

....At the same time these students need this kind of literature as graduates of the Canadian high school system. I mean, they need a bit of Shakespeare, Dickens, Canadian classics like 'Anne of Green Gables'. Who can dispute the lessons we learn from classics like 'Lord of the Flies' or Orwell's 'Animal Farm'?

(Mark Thompson, English teacher, Pearson Memorial High School) 
At the time of this study, Mark Thompson had been teaching English Language Arts and History at Pearson Memorial High School for all of his twenty year teaching career. Mr. Thompson believed strongly that both English and History had canonical bodies of knowledge that needed to be transmitted to all students and particularly to immigrant students "who do not really know much about this country's great history and the values that drive our civilization...".

A dedicated teacher with a proclaimed interest in the success of his new immigrant students, he was determined to help all his students succeed by teaching them the knowledge and values he felt they needed in order to be seen as "educated citizens, even if they don't all end up going to college..". At the same time, Mr. Thompson prided himself on holding high standards of academic excellence which he feared would be compromised if he used alternative teaching and assessment strategies to accommodate students who had not yet sufficiently mastered the English language. He commented:

Such compromises would give an unfair advantage to some students.... If these students cannot read and write English clearly, they should not be in an English literature course, at least until they are ready.

As he watched the student population change due to increasing immigration from non-European countries, Mr. Thompson became frustrated with his own inability to connect with new groups of students at a personal or an academic level. He lamented the good old days "when I met and chatted with parents in church or visited with them at home. Nowadays, with all the different language backgrounds I have in my classes, I can't do that so I don't know much about these students, really...". Relying mainly on text reading, text interpretation, and class presentation as his modes of instruction, he felt less successful in exciting students about literature. With an increasing number of students losing interest in History, Mr. Thompson was also eagerly looking forward to an early retirement from teaching when he turned fifty-five years of age.

\section{Changing students, changing practice}

An English major with a minor in History, Mr. Thompson taught Senior Years English (grades 10, 11, and 12), both the regular and the Advanced Placement (AP) sections, for most of his years at Pearson Memorial. He also taught History as part of Social Studies to senior years students. This combination gave him an excessive workload, teaching roughly 150 students over five or six periods per day. He admitted that this heavy student load affected his work in many ways:

Well, for example, I am not as effective as I would like to be, especially with my AP students who are almost all going to university. Even though their English classes are smaller, I don't get to give as much written work as I see fit because I have to attend to all those other classes and marking becomes a nightmare....

Mr. Thompson saw English the same way he saw History—as a pre-determined / canonical body of knowledge which students needed in order to be informed about Canada and western civilization in general: 
Let's not have any pretensions about this, immigrants come here because we have something, our values, if you will, that they admire. I have an obligation to teach those values through history and through literature. There are great stories in history that teach moral lessons which help students to develop into hardworking and productive citizens....Similarly, there are great works of literature to which all students must be exposed to be able to converse with intelligence.

Unlike Shirley Jones, Mr. Thompson had neither considered expanding the canon to include works of literature from countries other than the West, nor adapting the canon to the lives and experiences of the new population of students in his classrooms.

Mr. Thompson's goals for teaching English included "helping students become acquainted with the great literature of our tradition and become competent thinkers and writers... and hopefully, help them learn some moral lessons from literature...". As such he saw his role mainly as teaching academic content to students, particularly, covering the assigned literature texts and discussing literary elements such as theme, plot, figurative language, and allusions. Yet, while he required his AP students to make their own interpretations of literary allusions, he made no such demand on students in his regular classes: "I want them (regular students) to become competent thinkers and writers but I also know what their limits are...”. Mr. Thompson, however, gave his regular students, including his African refugee students, plenty of opportunity to write about issues arising from class discussions of literature. For example,

I ask them to write responses to a question like: How would your favourite character in 'Animal Farm' react to such and such incident? This gives them the chance to look at an issue from another's perspective.... Regrettably, some of the African students don't hand in their responses, I suspect because they really cannot do any sustained writing in the English language or do not fully understand what is required by the assignment."

Regrettably too, while he reported taking "great interest" in the academic success of his students, Mr. Thompson did not consider it his role to motivate students toward such success nor did he use alternative teaching methods that would enhance learning for EAL students like the African refugee students.

Although he said he was discouraged by the performance of EAL students like the African refugee students, claiming that these students receive more F's than others in his literature classes, he had not adapted his assessment practices to bring about success for the students. He gave less consideration to effort and class participation than all the teachers in our sample.

The department context did not appear to help Mr. Thompson make the changes needed when faced with new groups of students. According to him, teachers in his English department were divided into two camps: "Those of us who are still interested in teaching real literature and upholding standards and those who are bent on lowering standards to accommodate diversity". Unfortunately, those interested in teaching "real literature" did not spend much time discussing how best to continue teaching literary cannons to a changing student body. 
Overall, Mr. Thompson felt the demands posed by the changing student population in his school yet demonstrated very minimal forms of adaptation to them. His strong commitment to the literary canon and "academic excellence" prevented him from adapting his curriculum and grading and assessment while his limited instructional repertoire stymied his ability to adapt his instructional practices. At the time of this study, Mr. Thompson was struggling seriously with burn-out.

\section{Math teacher, Jim Paris}

Well again, there is the big difference with the African refugee kids, "cause some of them haven't attended school since they were nine or ten years old and then they come here and they're already sixteen....so there's been six to seven years of no schooling, you know, and because they are sixteen, they are placed in grade 10 but in actual fact they cannot function beyond grade 4 or 5 , so they need to go back to learning the basics. So my classroom is usually set where I go at a slower pace than probably everybody in the school but I have to go slow because the students need this remedial work to be able to catch up....so that's one way my teaching has changed.

Jim Paris was a young and energetic Black teacher who had taught Math and Physical Education for seven years at Pearson Memorial High School at the time of our study. He admitted that Math is slightly sequential but he was unusual amongst the Math teachers in our study in holding a view of Math as dynamic and less structured; he viewed Math as a discipline but also as a school subject that can be adapted to students. He strongly endorsed multiple goals for his students and, while committed to students learning the subject matter of Math and holding high standards for student achievement, he put equal emphasis on the development of citizenship skills, the nurturing of selfesteem, and what he called "a can-do spirit and attitude". He explained: "A can-do attitude is important for success in mathematics, as it is for many other things in life. You have to believe that you can do something, and then you apply yourself...”.

His knowledge of Math was deep and he utilized a variety of teaching methods and strategies including board work, use of computer programs, peer tutoring, cooperative group work, and as he put it, "whatever it takes to get students to grasp the concepts...", to engage his students.

At the time of our study, Mr. Paris was teaching a varied schedule ranging from Consumer Math in grade 10 to Pre-Calculus and Algebra in grades 11 and 12, as well as Physical Education which also included helping coach the school's soccer team. He reported that the time he spent with students in the gym and on the road as they traveled for soccer tournaments helped him develop rapport with students, a rapport that proved useful in motivating students to learn. Jim Paris' racialized position as a Black person who had immigrated from the Caribbean with his parents was a major factor in understanding the students' struggles and empathizing with them. He remarked:

It also helps that I am Black because they get motivated by my stories and experiences as a minority immigrant and how I was able to cope and apply myself to school work.... and they listen and make an effort.... 


\section{Changing students, changing practice}

Jim Paris admitted that, unlike some of the older teachers at Pearson Memorial High School with more experience, he did not find it particularly difficult to change his practice to meet the needs of the changing student population in his school. His teacher education program had emphasized student diversity, especially how to work with cultural diversity. Asked to explain more specifically how he applied his understanding of diversity to his teaching of Math, Mr. Paris replied:

Well, for example, I try to draw on students' prior knowledge and experiencewhat they already know about a concept - and I use that as a hook to the concept. The African kids we are talking about here, for example, one of them, he is from West Africa, he described a street game called "kpoyoi" played widely by kids in his home town. It's a neat game that can be used to teach addition and subtraction. It also teaches what certain positions mean in the game and so I used that prior knowledge to help him understand the concepts of negative and positive place values in Math....

Mr. Paris recognized what he called "issues" with which he had to deal when teaching new groups like the African refugee students at Pearson Memorial; issues such as their difficulty with the English language ("which makes it very difficult for them to decipher word problems"), less preparation for class, less home assistance with academic work, and less motivation. However, he did not see these issues as insurmountable obstacles interfering with the students' ability to learn Math. He described how he had tried to address some of these issues:

Take the language issue, for example. Math has its own language which you have to understand to know what is required of you in a word problem, for instance. So I teach students how to pick out the relevant information in a word problem. For example, what numbers are we looking for? What sentences tell you certain conditions? What sentences tell you numbers? What sentences tell you what you are going to do with those numbers? I do this mainly to help my EAL students but it benefits the whole class....

As a response to the lack of academic support available to students at home, Mr. Paris allocated 20 minutes of class time every day for doing homework. He explained:

Some of these students have no computers at home, no one to help them with assignments, not even a quiet spot to sit and work; some don't have time to do homework because they go to work right after school....so I give them 20 minutes to do their homework in class, as practice exercise. That way, I am right here in class when they need help.

He believed strongly that he was responsible for motivating students to learn mathematics, a belief shared by other members of his Math department. He described a number of ways in which he motivated students. For example, he told students about professions in the field of mathematics (e.g., engineering and architecture) and he also 
explained to students the uses of math in their daily lives. Believing strongly in an accepting, helpful atmosphere in the classroom, Mr. Paris encouraged peer coaching, especially among African students. He adapted curriculum content by actively participating in the planning and teaching of the modified Math program for the senior years and by slowing down the pace of his curriculum: "So my classroom is usually set where I go at a slower pace than probably everybody else in the school...". He, however, worried over the consequences of such slow pacing:

I worry about that because it means I may not be able to cover everything that I am supposed to cover in the Math curriculum and I worry because these students have to take exams that I do not get to set..."

Mr. Paris described a Math department that was supportive of teacher development and assumed collective responsibility for student learning. He attributed this strength to the current leadership of the department:

The leadership in the department has to believe that all students can succeed in Math and then work with us as a team to achieve that goal. I've seen that happening a lot over the past four years that Mr. C. has been department head....

In addition to strong departmental leadership and support, Mr. Paris also had a core group of Math colleagues "who believe, like I do, that we have kids who are turned

off Math, not kids who are too stupid to learn Math, and so we support each other and share ideas and techniques". He interacted regularly with these colleagues. They ate lunch together, conducted a lunch-time Math clinic for students, and informed each other about professional development opportunities and resources.

\section{Math teacher, Elizabeth Polsky}

Elizabeth Polsky had taught Pre-Calculus, Consumer Math, and Applied Math in grades 10, 11, and 12 at June Halloway High School for 23 years at the time of our study.

Ms. Polsky described her main goal for teaching Math as having students learn the Math content and skills that would prepare them for the next level course in the Math sequence. She saw broader goals such as those pertaining to citizenship skill or students' personal and social growth as being subsumed under this main goal:

My main focus is to get them through the syllabus and to learn what's on the syllabus to get them ready for the next grade. You cheat them if you don't cover all the Math units in the earlier class. In Math, the skills build on one another....I can teach citizenship and life skills while teaching Math content. For instance, Consumer Math is based on real life, like insurance, income tax, etc. These are all skills citizens need to learn....

Ms. Polsky expressed frustration with her current students, many of whom were new immigrants, because "they do not do their homework, or read the notes I give them, or 
apply themselves; the only way you get to be good at math is by practicing and practicing...."

To ensure mathematics learning, Ms. Polsky emphasized strong organizational and study skills. She described the new population of students in her classes as "very scattered when they come in and not at all organized". She required all of her students to keep notebooks and assignment sheets and to learn organizational and study skills; she got frustrated when students did not follow those procedures.

Ms. Polsky strongly believed that teacher-student relationship and interaction should be limited to academic matters and should not extend to the personal or social arenas. Therefore, even though she coached basketball, she did not appear to have a strong personal or social relationship with students. The following comment exemplified her belief about teacher-student relationships: "I coach basketball as well; okay, when we go on a tournament I take my work with me and between games, I sit down and do my work. I don't party or go around mixing...”.

Ms. Polsky's teaching methods strongly reflected her most important goalmastery of Math content and skills. When we observed her classes, her teaching was heavily teacher-directed and she demonstrated many of the hallmarks of conventional teaching. Each class began with a step-by-step review of previously assigned Math homework on the board, followed by corrections. A lecture and demonstration were then used to introduce a new Math topic after which students were required to practice the new Math skill through individual seat-work while Ms. Polsky walked around to give individual help. During our discussion about the use of alternative teaching methods such as cooperative group work, she commented, "Cooperative learning is intended to help students learn to work together but does that help them learn the math skills? Not in my opinion". Peer coaching was disparaged by Ms. Polsky as an opportunity for weak students to get a free ride: "The weak students simply copied the work of students supposedly coaching them. So when I noticed that, I would simply stop them and take over...". Education assistants were similarly disparaged: "They are not certified teachers so they don't really know how to teach or give one-on-one instruction. They do all the work for the students. I don't trust them". She held a highly sequential view of mathematics and adhered to the ideal that Math is a series of skills to be learned in a set order. This sequential view of Math was the reasoning behind Ms. Polsky's strong belief in "the proper placement of students". It also explains why she saw it as "cheating the students" if a teacher did not cover every topic on a Math syllabus. Her conceptions of the subject matter of Math as clearly defined, fixed, and sequential were more pronounced than the other Math teachers in our larger study.

\section{Changing students, changing practice}

Although Ms. Polsky appeared quite well informed about the disrupted schooling background of the war-affected African refugee students in her classes, she made minimal adaptation in her curriculum, teaching, and assessment practices to accommodate this new population of students. She acknowledged the limited English language proficiency of these students ("which makes it extremely difficult for them to understand the course material"), yet the only adaptations she reported making were to give notes and vocabulary which the students hardly understood. She reported a general lack of motivation among students across the board in terms of their desire to do home 
work, ask questions, or study their notes, but felt very strongly that students should motivate themselves. She commented:

....My responsibility is to give the notes and examples and make myself available for questions but I can't force them to read those notes, or practice the math skills or ask questions in class; they have to motivate themselves to do that....

Although she acknowledged that, as newcomers, African refugee students had to wrestle with issues such as social integration and learning a new language and culture, she believed it was primarily a lack of motivation and effort that stood in their way to school success. However, her preoccupation with subject matter coverage and "fairness to deserving students" left her feeling reluctant (?) to making adaptations that would motivate this group of students. She said:

You know what? I really wish we could do something more for these students because I feel bad for them but my hands are tied....if I slow down then the kids who deserve to have the course are cheated....because then I cannot cover everything that needs to be covered....

The Math department which Ms. Polsky headed generally reinforced her beliefs about subject matter, student placement, and goals for mathematics. At the time of this study, the department was pushing hard to develop a standardized placement testing program to determine student eligibility for Math courses. With a strong commitment to sequential mathematics accompanied by a skill orientation, the Math teachers at June Halloway felt that tests defined the necessary skills for each course. Department members reported very little interaction among themselves. They seldom met as a department because, according to Ms. Polsky,

Everyone is so busy....And with the new Math curriculum, they are busy attending workshops on delivering this new curriculum. It's hard to get everyone together for a meeting....

As head of the Math department, Ms. Polsky described her role this way: "To guide the teachers in their presentation of courses, to make sure the courses are being presented in their entirety, and to make suggestions as to how to do so effectively...". When they managed to meet as a department, the discussions were mostly devoted to routine matters like budgeting and timetabling. Ms. Polsky acknowledged that African refugee students were experiencing severe difficulty with Math and were dropping out of Math classes, especially her own Math courses. When asked what the Math department had done to address this problem, she responded by reiterating the lack of effort by the students themselves and by laying some of the blame on the school administration:

I have repeatedly made it clear to administration that these students need prerequisite courses in all areas of Math but no one listens, and I can only make suggestions. I cannot enforce anything. There is nothing that I or the department can do.... 
I was left with the impression of an ineffectual department that was not particularly concerned with change and experimentation in the face of new groups of students, a department that seemed to share common perspectives and beliefs about students and subject matter that were stuck in the past.

\section{Discussion}

Shirley Jones, Mark Thompson, Jim Paris, and Elizabeth Polsky are all wellregarded, dedicated teachers who want their students to succeed. However, while Shirley Jones and Jim Paris appeared to have reconceptualized their curricula and instructional practices and made specific changes to adapt to the changing student population in their schools, Mark Thompson and Elizabeth Polsky made few such changes and reported being frustrated and unable to reach students. Why are some teachers able to reconceptualize and adapt their teaching to diverse students while others make limited adjustments? To answer this question, I briefly examine the teaching goals, conceptions of subject matter, individual teacher characteristics, and department contexts of our case study teachers for commonalities and differences.

\section{Goals}

Despite different school subjects, Shirley Jones and Jim Paris shared similar patterns of teaching goals. Both held multiple goals for their students that encompassed subject matter learning, personal growth, and the development of positive, social skills. In the eyes of these two teachers, academic learning was no more important than social and personal development. In contrast, Mark Thompson and Elizabeth Polsky held in common the preeminent goal of subject matter mastery, a goal that appeared to dismiss students' personal and social development. By their own admission, subject matter coverage and mastery were more important than those to whom it was taught; whatever adjustments Thompson and Polsky made to their curricula and instruction were focused entirely on academic achievement defined by criteria that seemed oblivious to a changing student body.

It therefore appears that holding multiple goals may make it easier for teachers to adapt curricula and instructional practices. This raises the question, however, of whether or not pursuing multiple goals might compromise the quality of academic achievement of students. Stodolsky and Grossman (2000) point out that teachers like Shirley Jones, who hold multiple goals, typically see multiple goals as synergistic; each goal facilitates the successful development of the others. It is possible, however, that Shirley Jones' decision to pass students in her regular classes (many of them new immigrant students) based on effort and regular attendance - an adaptation she admitted was inconceivable when it came to her university bound students - might have under-played subject matter learning and led to lowered expectations for her regular students.

\section{Teachers' personal characteristics}

Shirley Jones and Jim Paris used their personal connections with students to engage them in the subject matter and to motivate the students to learn. Mr. Paris enjoyed the personal interactions he had with students and capitalized on these relationships in the 
Math classroom. He encouraged the students by disclosing his personal experiences as a Black immigrant student and how he had coped with school. Shirley Jones not only took sufficient personal interest in her students to get to know their backgrounds and life circumstances, she also used this knowledge to inform the adaptations she made in her curriculum and pedagogy to foster success for the students. On the contrary, Mr. Thompson lamented the lost personal connections of yesteryear when, because of the similarity of their culture and language to his own, he would visit his students' families or converse with them at church. Elizabeth Polsky firmly believed that interactions between teacher and students should be limited to matters of academic learning, even in her basketball coaching classes. Neither Mr. Thompson nor Ms. Polsky saw it as their responsibility to motivate students, believing strongly that students should motivate and apply themselves in order to succeed.

Another marked difference between the case study teachers can be seen in their instructional repertoires. While Jim Paris and Shirley Jones were willing to try new teaching methods and resources to reach diverse students, Mark Thompson and Elizabeth Polsky did not appear to have the proclivity to try alternative methods or resources. They had limited repertoires of instructional strategies with which they were comfortable and both were skeptical of alternative instructional and assessment approaches, fearing that such approaches would compromise subject matter learning and high academic standards. It is possible that Ms. Polsky's and Mr. Thompson's strong commitments to subject matter coverage and conceptions of subject matter as fixed bodies of knowledge to be transmitted to students may be responsible for their lack of faith in the potential of these new approaches.

\section{Conceptions of subject matter}

As pointed out earlier in the conceptual framework, in general, Math and English teachers view their subjects differently which leads to different contexts for curricular and instructional decision making. Math teachers tend to see their subject as well-defined, sequential, and with non-negotiable content, a view that may constrain Math teachers' perceived opportunities for adaptation. English teachers, on the other hand, tend to have a flexible conception of their subject which may create an environment more conducive to adaptation. According to our data, however, what is true of Math and English teachers in general is much less true of Jim Paris, an adaptive Math teacher, and Mark Thompson, an unadaptive English teacher, thus suggesting that teachers' individual beliefs and conceptions of subject areas matter enormously. Mr. Paris is unusual in rejecting a strong sequential definition of Mathematics. Although he agreed that pre-requisite skills were important for the next level of Math, he also believed that students could learn more advanced concepts before mastering basic skills. In contrast, Ms. Polsky's strong commitment to the importance of sequence and pre-requisite skills made it difficult for her to entertain alternative approaches to the teaching and learning of mathematics, preferring instead that all new immigrant students be tested to determine proper placement for Math.

Similarly, while Shirley Jones' flexible conceptions of English allowed greater autonomy to make curricular and instructional adaptations in response to the needs of new students, Mr. Thompson's disciplinary conception of English as organized around established canons that foster cultural literacy allowed him fewer degrees of freedom to 
make adaptations. For Mr. Thompson substituting another author for the prescribed canon was not an option.

Across the two school subjects, it appeared that the teachers with more flexible conceptions of subject matter were better poised to adapt their teaching to a changing student population. Although Mr. Paris and Ms. Jones taught different subjects, similarities in their broad goals for students and flexible conceptions of subject matter extended well beyond the specific subject areas. On the other hand, Ms. Polsky's and Mr. Thompson's narrow goals and rigid conception of subject matter constrained their abilities to adapt their curricula.

\section{School contexts}

Our research data confirm Siskin and Little's (1995) conclusion that contextual factors such as the subject department of teachers, professional development opportunities, collegial support, and workload present one of the most important influences on teachers' ability and willingness to change their practices when faced with a changing student population. While individual teacher's attributes, goals, and conceptions of subject matter may make it more likely that a teacher will consider new practices, department and collegial support for such effort can play a role in providing opportunities for new learning. For example, the network of support groups experienced by Shirley Jones, her comfortable teaching load, and available professional development opportunities enhanced her self-efficacy and confidence to embark on new practices. Conversely, negative departmental norms, limited collegial interactions, and general lack of interest in change in the cases of Ms. Polsky and Mr. Thompson reinforced and sustained their personal reluctance to experiment with new practices.

\section{Conclusion}

Our study shows that some public school teachers are making conscious efforts to adapt their curricula and teaching practices to meet the learning needs of a changing school population while others have yet to make any meaningful changes in their practices. Significantly however, the study also reveals that the tendency to adapt or to not adapt to changing student populations correlated with a number of individual and institutional factors that clearly went beyond knowledge of cultural diversity. the Mantra of teacher education programs across Canada. A dynamic conception of subject matter, multiple goals, supportive school contexts, and healthy personal relationships with students were common elements among teachers who adapted their practices to better serve diverse student populations. A major challenge for these teachers, however, was how to adapt effectively without lowering expectations for students in the subject matter.

As the face of public education students in Canada changes, the need intensifies to understand more fully what equips teachers to respond successfully to diverse populations like African refugee students. This study is important to the extent that it has identified factors, that influence teachers' ability and willingness to adapt to the demographic changes occurring in schools. The study, therefore, has policy implications for teacher education programs which must now reconsider individual and institutional factors in preparing teachers for curricular adaptation, and schools which must provide the contextual supports that should accompany teacher change. 


\section{Notes}

1. Pseudonyms are used for the schools and research participants in this paper.

\section{References}

Abowitz, K.K. \& Harnish, J. (2006). Contemporary discourses of citizenship. Review of Educational Research, 76 (4), 653-690.

Banks, J. (2008). Diversity, group identity, and citizenship education in a global age. Educational Researcher, 37 (3), 129-139.

Cole, M. \& Wertsch, J. V. (1996). Beyond individual-social antimony in discussions about Piaget and Vygotsky. Human Development, 39, 250-256

Darling-Hammond, L. \& Bransford, J..(2005). Introduction. In L. Darling-Hammond \& J. Bransford (Eds.), Preparing teachers for a changing world: What teachers should learn and be able to do (pp. 1-39). New York: Jossey-Bass.

Grossman, P. L. \& Stodolsky, S. S. (1995). Content as context: The role of school subjects in secondary school teaching. Educational Researcher, 24 (8), 5-11.

Knapp, M. S. (1995). Introduction: the teaching challenge in high poverty classrooms. . In M.S. Knapp (Ed.), Teaching for meaning in high-poverty classrooms (pp.1-10). New York: Teachers College Press.

Mackay, T. \& Tavares, T. (2005). Building hope: Appropriate programming for adolescent and young adult newcomers of war-affected backgrounds and Manitoba schools: A preliminary report for consultation and discussion, October 20, 2005. Winnipeg, MB: Manitoba Education, Training and Citizenship.

Morrish, M. (2006). Manitoba immigration and integration initiatives. Presented by Margot Morrish at PCERII Annual Planning Meeting, Edmonton, AB. Feb., 2006.

Nieto, S. (1996). Affirming diversity: The socio-political context of multicultural education. New York: Longman Press.

Page, R. N. (1991). Lower-track classrooms: A curricular and cultural perspective. New York: Teachers College Press.

Siskin, L. S. \& Little, J. W. (1995). The subject in question: Departmental organization and the high school. New York: Teachers College Press.

Stodolsky, S. S. \& Grossman, P. L. (2000). Changing students, changing teaching. Teachers College Record, 102 (1), 125-172.

Vygotsky, L. S. (1981). The genesis of higher mental functions. In J. V. Wertsch (Ed.), The concept of activity in Soviet psychology, (pp. 144-188). Armonk, NY: Sharpe. 